\title{
Comparison of controlling mechanisms of flocculation processes in estuaries
}

\author{
${ }^{1 * A . ~ B i a t i ; ~}{ }^{2}$ A. R. Karbassi \\ ${ }^{1}$ Department of Environmental Science, Graduate School of the Environment and Energy, Science and Research \\ Branch, Islamic Azad University, Tehran, Iran \\ ${ }^{2}$ Graduate Faculty of the Environment, University of Tehran, P.O.Box 14155-6135, Tehran, Iran \\ Received 24 May 2010; revised 2 July 2010; accepted 10 August 2010; available online 1 September 2010
}

\begin{abstract}
During estuarine mixing, dissolved metals come into the particulate phase due to the flocculation processes. Such processes are biologically vital. In the present study, controlling mechanisms of elemental flocculation during estuarine mixing in northern and southern estuaries of Iran in relation to the various physical and chemical parameters of waters have been compared. Except for zinc and lead, for other studied elements in Minab River, water flocculate at higher rates in comparison with the rivers flowing into the Caspian Sea. Redox potential might have negative effect on flocculation process in Minab Estuary. Contrary to rivers flowing into the Caspian Sea, in Minab River elemental flocculation is governed by dissolved organic carbon and it shows a non-liner and conservative behavior during estuarine mixing which implies that dissolved organic carbon originates from terrigenous source. The results also shows that maximum removal of elements occurs in lower salinities (1.5 to $5.8 \%$ ) for the rivers in North of Iran and 3.3 to $11.4 \%$ for Minab River in South of Iran. Flocculation of studied metal in different rivers results in reduction of overall metal pollution load by various percentages. The initial metal contents on river water and mean discharge of river might lead to higher flocculation rates.
\end{abstract}

Key words: Estuarine processes; Metals; Purification; Removal; River

\section{INTRODUCTION}

An estuary is a semi- enclosed coastal body of water which has a free connection with the open sea and within which sea water is measurably diluted with fresh water derived from land drainage (Pritchard, 1967). It is a very productive biome and supports biogeochemical cycling, maintenance of biological production, movement of nutrients and etc. (Meire, 2005; Samarghandi et al., 2007; Hassani et al., 2008). Information on the variability of the existence forms of microelements in estuarine waters is necessary in order to understand their behavior in passing through the geochemical barrier and their effect on estuarine ecology (Anikiev and Goryachev, 1991; Achterberg et al., 2003; Savchenko, 2009). Flocculation of dissolved metals can significantly affect the chemical mass balance between rivers and seas or lakes. During estuarine mixing, dissolved metals come into the particulate phase due to the flocculation process. Salinity may inhibit the vertical turbulent eddies due to a vertical density gradient and can influence sediment transport through increased flocculation (Eckert and Sholkovitz,

ه *Corresponding Author Email: bayati_id@yahoo.com Tel./Fax: +989123777164
1976; Boyle et al., 1977; Sholkovitz et al., 1977). Some researchers have mainly focused on salinity, $\mathrm{pH}$, colloidal stability, surface properties, humic acids, turbulence and concentration of suspended matters, ionic strength and algal concentration as the main governing factors or flocculation of trace metals during estuarine mixing. (Hunter, 1983; Zhiqing et al., 1987; Shankar and Karbassi 1992; Featherstone and O’Grady, 1997; Matagi et al., 1998). Due to growing concern over the divers effects of heavy metals and their compounds on aquatic ecosystems, many investigations have been carried out on dissolved elemental concentrations and then controlling mechanisms in some rivers flowing in to the Caspian Sea in North of Iran and the Persian Gulf in the South of Iran (Karbassi and Nadjafpour, 1996; Saeedi et al., 2003; Karbassi et al., 2007, Karbassi et al., 2008 a,b; Biati et al., 2010 b). In the present study, controlling mechanisms of elemental flocculation during estuarine mixing in northern and southern estuaries of Iran in relation to the various physical- chemical parameters of water are compared. 


\section{MATERIALS AND METHODS}

Minab River has a length of $200 \mathrm{Km}$ and its average annual discharge is $10.99 \mathrm{~m}^{3} / \mathrm{s}$. Minab River is formed by two main branches named Rudan in western part and Jaghin in eastern part. It lies between longitude of $57^{\circ}$ $07^{\prime}$ and Latitude of $27^{\circ} 09^{\prime}$. Annual average of sediment load weights of River in Berentin Station has been estimated at 5920 ton $/ \mathrm{km}^{3} / \mathrm{y}$. Various municipal and industrial wastewater containing heavy metals and organics along with agricultural fertilizers, pesticides and herbicides enter into the Minab River. Freshwater samples were collected from the Minab River (ca. $16 \mathrm{Km}$ upstream) in a $25 \mathrm{~L}$ clean polyethylene bucket from the surface. On the same day, it was filtered through 0.45 $\mu \mathrm{m}$ Millipore APand HA filters (Biati et al., 2010b). About one liter of filtered water was acidified with concentrated $\mathrm{HNO}_{3}$ to a $\mathrm{pH}$ of approximately 1.8 and stored in polyethylene bottles in a refrigerator prior to the analysis of dissolved metals. The rest of filtered waters were also kept in refrigerator. On the same day, Persian Gulf water was collected approximately $20 \mathrm{Km}$ away from the coast to ensure that the sample was not diluted by river water. In order to prevent the contamination of samples, all equipment was acid washed with a mixture of $\mathrm{HNO}_{3}$ and $\mathrm{HCl}$. Rinsing was done with running Milli-Q water. Filtered river water and sea water were mixed together at room temperature in various proportions yielding 9 different proportions of salinity (3.3-29.9\%). They were kept for $24 \mathrm{~h}$ with occasional stirring. The resulting flocculants were collected on $2.5 \mathrm{Cm}$ diameter Millipore membrane filters (type HA, Pore size: $0.45 \mu \mathrm{m}$ ). Millipore filters were digested by $5 \mathrm{~mL}$ concentrated $\mathrm{HNO}_{3}$ overnight. The concentrations of $\mathrm{Cu}, \mathrm{Zn}, \mathrm{Ni}, \mathrm{Pb}$ and $\mathrm{Mn}$ were determined by ICP (JOBINYVON model JY 138 ULTRACE). Procedural blanks and duplicates were run with the samples in a similar way. Calibration ICP was done by dilution of single concentrated standards purchased from SPEX $X_{\text {Cerprep }}$ Company. The accuracy of the analysis was about $\pm 5 \%$ for all elements in the dissolved and flocculants phases. It should be noted that salinity of fresh water and seawater in sampling station was measured using portable apparatus. Of the existing clustering techniques (Lance and William, 1966; Anderson, 1971; Davis, 1973) the Weighted Pair Group (WPG) method (Davis, 1973) was used in this study.

\section{RESULTS AND DISCUSSION}

At laboratory scale fresh water with its initial trace metal contents is mixed up with saline water while in the nature fresh water does not mix up with saline water as same as laboratory scale. At very first stage of mixing of river water with saline water, some of dissolved metals ooze out of the fresh water in the form of flocculants. Thus, at the later stage of mixing (i.e. higher salinities) fresh water is impoverished in base metals and fewer flocculants form (Table 1). About 117 $\mu$ g/L of total Zn contents flocculates during estuarine mixing (about $5 \%$ ). The maximum flocculation of $\mathrm{Zn}$ occurs at salinities of 3.3 and $29.9 \%$, respectively (37 and $36 \mu \mathrm{g} / \mathrm{L}$ ). In other

Table 1: Mean actual concentration of elements in flocculants along with salinity in Minab River (Biati et al., 2010)

\begin{tabular}{|c|c|c|c|c|c|c|}
\hline Elements & $\mathrm{Zn}$ & $\mathrm{Pb}$ & $\mathrm{Ni}$ & $\mathrm{Cu}$ & Mn & $\mathrm{S}$ \\
\hline Aquarium No. & & & $(\mu \mathrm{g} / \mathrm{L})$ & & & (\%o) \\
\hline Minab River water & 117 & 50 & 88 & 36 & 259 & 0.72 \\
\hline (t) & $\begin{array}{c}37 \\
(31.6)^{*}\end{array}$ & $\begin{array}{r}5 \\
(10)\end{array}$ & $\begin{array}{r}55 \\
(62.6)\end{array}$ & $\begin{array}{r}14 \\
(38.9)\end{array}$ & $\begin{array}{r}85 \\
(32.8)\end{array}$ & 3.3 \\
\hline 2 & $\begin{array}{r}0 \\
(0)\end{array}$ & $\begin{array}{r}14 \\
(28)\end{array}$ & $\begin{array}{r}1 \\
(1.1)\end{array}$ & $\begin{array}{r}6 \\
(16.7)\end{array}$ & $\begin{array}{r}48 \\
(18.5)\end{array}$ & 8.3 \\
\hline 3 & $\begin{array}{r}9 \\
(7.7)\end{array}$ & $\begin{array}{r}0 \\
(0)\end{array}$ & $\begin{array}{r}2 \\
(2.3)\end{array}$ & $\begin{array}{r}6 \\
(16.7)\end{array}$ & $\begin{array}{r}0 \\
(0)\end{array}$ & 9.1 \\
\hline 4 & $\begin{array}{r}6 \\
(5.1)\end{array}$ & $\begin{array}{r}0 \\
(0)\end{array}$ & $\begin{array}{r}1 \\
(1.1)\end{array}$ & $\begin{array}{r}0 \\
(0)\end{array}$ & $\begin{array}{r}42 \\
(16.2)\end{array}$ & 11.4 \\
\hline 5 & $\begin{array}{r}0 \\
(0)\end{array}$ & $\begin{array}{r}0 \\
(0)\end{array}$ & $\begin{array}{r}14 \\
(15.9)\end{array}$ & $\begin{array}{r}0 \\
(0)\end{array}$ & $\begin{array}{r}0 \\
(0)\end{array}$ & 14.5 \\
\hline 6 & $\begin{array}{r}0 \\
(0)\end{array}$ & $\begin{array}{r}0 \\
(0)\end{array}$ & $\begin{array}{r}0 \\
(0)\end{array}$ & $\begin{array}{r}0 \\
(0)\end{array}$ & $\begin{array}{r}5 \\
(1.9)\end{array}$ & 18.5 \\
\hline 7 & $\begin{array}{r}0 \\
(0)\end{array}$ & $\begin{array}{r}0 \\
(0)\end{array}$ & $\begin{array}{r}0 \\
(0)\end{array}$ & $\begin{array}{r}2 \\
(5.5)\end{array}$ & $\begin{array}{r}0 \\
(0)\end{array}$ & 26.7 \\
\hline 8 & $\begin{array}{r}0 \\
(0)\end{array}$ & $\begin{array}{r}0 \\
(0)\end{array}$ & $\begin{array}{r}0 \\
(0)\end{array}$ & $\begin{array}{r}2 \\
(5.5)\end{array}$ & $\begin{array}{r}0 \\
(0)\end{array}$ & 28.8 \\
\hline 9 & $\begin{array}{r}36 \\
(30.80)\end{array}$ & $\begin{array}{r}0 \\
(0)\end{array}$ & $\begin{array}{r}0 \\
(0)\end{array}$ & $\begin{array}{r}0 \\
(0)\end{array}$ & $\begin{array}{r}0 \\
(0)\end{array}$ & 29.9 \\
\hline Total & $\begin{array}{r}88 \\
(75.2)\end{array}$ & $\begin{array}{r}19 \\
(38)\end{array}$ & $\begin{array}{r}73 \\
(82.9)\end{array}$ & $\begin{array}{r}30 \\
(83.3)\end{array}$ & $\begin{array}{r}180 \\
(69.4)\end{array}$ & - \\
\hline
\end{tabular}

* The amounts in parentheses are indicated as percentage of removal 
salinities, flocculation of $\mathrm{Zn}$ is not significant. Amongst studied metals, only Zn flocculates at the highest salinity (29.9 \%). About $38 \%$ of total $\mathrm{Pb}$ content flocculates during estuarine mixing which is equal to $19 \mu \mathrm{g} / \mathrm{L}$. Flocculation of $\mathrm{Pb}$ occurs at salinity of 3.3 and $8.3 \%$ and this behavior makes it exceptional amongst other studied metals. The highest flocculation of $\mathrm{Ni}$ (about $55 \mu \mathrm{g} / \mathrm{L}$ ) is found at salinity of $3.3 \%$. In salinity of 8.3 to $11.4 \%$, flocculation of Ni ranges from 1 to $2 \mu \mathrm{g} / \mathrm{L}$ and increases in salinity of $14.5 \%$. Flocculation of Ni does not occur in salinities higher than $14.5 \%$. Generally, total flocculation of $\mathrm{Ni}$ (similar to $\mathrm{Cu}$ ) during estuarine mixing is about $83 \%(73 \mu \mathrm{g} / \mathrm{L})$. The highest flocculation of $\mathrm{Cu}$ (same as $\mathrm{Zn}$ and $\mathrm{Ni}$ ) occurs at salinity of $3.3 \%$. However, the flocculation is found in salinity of 8.3 and $9.1 \%$ and to a lower extent at 26.7 and $28.8 \%$. About 70 $\%$ of initial content of $\mathrm{Mn}$ flocculates during estuarine mixing and most of it occurs at salinity of $3.3 \%$ (about $83 \%$ ). Flocculation of Mn can be also traced in salinity of 8.3 and $11.4 \%$. The concentration of studied metals in Minab River water during estuarine mixing has been compared with the concentration of elements in flocculants of five rivers flowing into the Caspian Sea in North of Iran (Table 2). As can be seen in Table 2, except for $\mathrm{Zn}$ and $\mathrm{Pb}$ other studied elements in Minab River water flocculate at higher rates in comparison with the river flowing into the Caspian Sea (Karbassi and Nadjafpour, 1996; Saeedi et al., 2003; Karbassi et al., 2007; Karbassi et al., 2008a,b) and this might be due to higher initial metal contents in Minab River water than the northern river of Iran (Biati et al, 2010 b). The lowest flocculation rate in Minab river is associated with $\mathrm{Pb}$ (38 $\%$ ) and in Tadjan, Talar, Babolrud and Haraz (Rivers flowing into the Caspian Sea) Ni flocculates in the lowest rate $(7.1 \%, 18.8 \%, 12.2 \%$ and $11.3 \%$, respectively). In
Shirud River Zn shows the lowest flocculation rate which is in contrast with the other studied rivers in the North. An almost conservative behavior of $\mathrm{Ni}$ in Haraz, Babolrud and Talar estuaries is incompatible with the findings of nearby estuary (Tadjan Estuary). Copper has highest flocculation rate amongst studied metal only in Minab, Babolrud and Shirud Rivers but in the other rivers maximum flocculation rate can be found for $\mathrm{Zn}$. The highest flocculation rate of $\mathrm{Zn}$ occurs in Tadjan river (96.6\%). Moreover, the widest range of flocculation rate is found in Tadjan River (from $7 \%$ to $97 \%$ ). General pattern of flocculation rate of the seven mentioned rivers is as follows:

Minab: $\mathrm{Cu}(83.3 \%)>\mathrm{Ni}(82.9 \%)>\mathrm{Zn}(75.2 \%)>\operatorname{Mn}(69.4$ $\%)>\mathrm{Pb}(38 \%)$

Tadjan: $\mathrm{Zn}(96.6 \%)>\mathrm{Mn}(51.7 \%)>\mathrm{Cu}(41.7 \%)>\mathrm{Ni}(7.1 \%)$

Talar: $\mathrm{Zn}(72.5 \%)>\mathrm{Mn}(52.3 \%)>\mathrm{Cu}(48 \%)>\mathrm{Pb}(27.5 \%)$ $>\operatorname{Ni}(18.8 \%)$

Babolrud: $\mathrm{Cu}(77.9 \%)>\mathrm{Zn}(74.6 \%)>\mathrm{Mn}(64.97 \%)>\mathrm{Pb}$ (38.2\%) > Ni(12.2\%)

Haraz: $\mathrm{Zn}(85.5 \%)>\mathrm{Mn}(55.2 \%)>\mathrm{Cu}(39.6 \%)>\mathrm{Pb}(33.7$ $\%)>\mathrm{Ni}(11.3 \%)$

Shirud: $\mathrm{Cu}(74 \%)>\mathrm{Pb}(61 \%)>\mathrm{Mn}(58 \%)>\mathrm{Zn}(34 \%)$

Range of salinities in obtained series of mixtures resulting from mixing of river water with the saline water in different proportions in Minab River varies from 3.3 to $29.9 \%$ and in the rivers flowing into the Caspian Sea ranges from about 1.5 to approximately $9.5 \%$ (Table 2).Thus, it can be inferred from data given in Table 2 that rapid flocculation occurs in the earlier stages of mixing of fresh water with the saline water (salinity of 3.3 to 11.4 for Minab River, salinity of 1.5 to 5.5 for Tadjan, Talar, Babolrud and Haraz Rivers and salinity of 3.2 to 5.8 for Shirud River). This is in accordance with the findings of other researchers (Duinker and Nolting, 1978; Bewers et

Table 2: Concentration of elements in flocculants and effective range of salinity in six rivers

\begin{tabular}{|c|c|c|c|c|c|c|c|c|}
\hline \multirow[b]{3}{*}{ River } & \multicolumn{5}{|c|}{ Elements } & \multirow{3}{*}{$\begin{array}{l}\text { Range of } \\
\text { salinity in } \\
\text { series of } \\
\text { mixtures (\%o) }\end{array}$} & \multirow{3}{*}{$\begin{array}{l}\text { Most importanı } \\
\text { salinity ranges } \\
\text { flocculation of } \\
\text { metals (\%o) }\end{array}$} & \multirow{3}{*}{ Reference } \\
\hline & \multicolumn{5}{|c|}{ Concentration of elements in flocculants $(\mu \mathrm{g} / \mathrm{L})$} & & & \\
\hline & $\mathrm{Zn}$ & $\mathrm{Pb}$ & $\mathrm{Cu}$ & $\mathrm{Mn}$ & $\mathrm{Ni}$ & & & \\
\hline Minab & $\begin{array}{c}88 \\
(75.2)^{*}\end{array}$ & $\begin{array}{r}19 \\
(38)\end{array}$ & $\begin{array}{r}30 \\
(83.3)\end{array}$ & $\begin{array}{r}180 \\
(69.4)\end{array}$ & $\begin{array}{r}73 \\
(82.9)\end{array}$ & 3.3-29.9 & 3.3-11.4 & Biati et al. (2010a) \\
\hline Tadjan & $\begin{array}{r}57 \\
(96.9)\end{array}$ & $\begin{array}{l}\text { ND* } \\
\text { ND }\end{array}$ & $\begin{array}{r}4.7 \\
(41.7)\end{array}$ & $\begin{array}{r}12.1 \\
(51.7)\end{array}$ & $\begin{array}{r}2.8 \\
(7.1)\end{array}$ & $1.52-9.52$ & $1.5-5.5$ & Saeedi et al. (2003) \\
\hline Talar & $\begin{array}{r}62.4 \\
(72.5)\end{array}$ & $\begin{array}{r}11.6 \\
(27.5)\end{array}$ & $\begin{array}{l}14.9 \\
(48)\end{array}$ & $\begin{array}{r}15.6 \\
(52.3)\end{array}$ & $\begin{array}{r}4.7 \\
(18.8)\end{array}$ & $1.50-9.50$ & $1.5-3.5$ & Karbassi et al. (2007) \\
\hline Babolrud & $\begin{array}{r}63.4 \\
(74.6)\end{array}$ & $\begin{array}{r}8.42 \\
(38.2)\end{array}$ & $\begin{array}{r}16.2 \\
(77.9)\end{array}$ & $\begin{array}{r}12.8 \\
(64.97)\end{array}$ & $\begin{array}{r}4.90 \\
(12.2)\end{array}$ & $1.55-9.55$ & $1.5-3.5$ & $\begin{array}{l}\text { Karbassi et al. } \\
\text { (2008a) }\end{array}$ \\
\hline Haraz & $\begin{array}{l}81.29 \\
(85.5)\end{array}$ & $\begin{array}{r}8.42 \\
(33.7)\end{array}$ & $\begin{array}{l}14.25 \\
(39.6)\end{array}$ & $\begin{array}{r}13.8 \\
(55.2)\end{array}$ & $\begin{array}{r}5.07 \\
(11.3)\end{array}$ & $1.50-9.50$ & $1.5-4.5$ & $\begin{array}{l}\text { Karbassi et al. } \\
\text { (2008b) }\end{array}$ \\
\hline Shirud & $\begin{array}{l}27.5 \\
(34) \\
\end{array}$ & $\begin{array}{l}15.8 \\
(61)\end{array}$ & $\begin{array}{l}20.0 \\
(74)\end{array}$ & $\begin{array}{r}9.2 \\
(58) \\
\end{array}$ & - & 3.2-7.4 & $3.2-5.8$ & $\begin{array}{l}\text { Karbassi and } \\
\text { Nadjafpour (1996) }\end{array}$ \\
\hline
\end{tabular}

* Not Detected; ** The amounts in parentheses are as indicated percentage of removal 
al., 1974); though at relatively higher salinities. Higher removal of heavy metals at greater salinities is reported by Biati et al (2010a).

Biati et al. (2010b) showed that $\mathrm{pH}$, temperature, DO, alkalinity, $\mathrm{HCO}_{3}, \mathrm{CO}_{3}$, EC, salinity, $\mathrm{Na}, \mathrm{Cl}, \mathrm{Mg}, \mathrm{SO}_{4}$ and $\mathrm{Ca}$ do not have any role on the flocculation process during mixing of the Minab River water with the Persian Gulf waters. Redox potential might have reverse effect in flocculation process in Minab estuary. Amongst all studied physical-chemical parameters only dissolved organic carbon (DOC) showed high similarity coefficient with $\mathrm{Cu}, \mathrm{Zn}$, Ni and Mn. Though, DOC has a little influence on the flocculation of Pb. Therefore, DOC is the main governing factor for the flocculation of $\mathrm{Zn}, \mathrm{Ni}$, $\mathrm{Cu}$ and $\mathrm{Mn}$ in the Minab estuary (Table 3). This finding is in agreement with studies of Sholkovitz (1976), Mantoura and Woodward (1983) and Meyer (1983). In contrast, in studies of rivers flowing into the Caspian Sea DOC does not play an important role in flocculation Process. Karbassi et al. (2007) and Karbassi et al. (2008a) reported that flocculation of $\mathrm{Zn}, \mathrm{Ni}$ and $\mathrm{Cu}$ is controlled by $\mathrm{pH}$ and total nitrogen $\left(\mathrm{N}_{\mathrm{T}}\right)$ during mixing of Talar and Haraz rivers with Caspian Sea water. Statistical analysis reveals that the flocculation of dissolved metals in Tadjan river which is governed by $\mathrm{pH}$ has an inverse relationship with TOC, EC and salinity. This suggests that increasing salinity, TOC and EC leads to a decrease of pH and elemental flocculation (Saeedi et al., 2003). Karbassi and Nadjafpour (1996) concluded that in Shirud Estuary, the main governing factor of metal flocculation ( $\mathrm{Pb}$ and $\mathrm{Zn}$ ) is salinity. Biati et al (2010a) stated that the removal of dissolved metals ( $\mathrm{Zn}, \mathrm{Mn}$ ) from waste waters is not influenced by DOC. Electrical conductivity, $\mathrm{pH}$, salinity and $\mathrm{Cl}$ show significant role in flocculation of $\mathrm{Zn}$ and $\mathrm{Mn}$ from wastewaters. Removal of $\mathrm{Ni}$ and $\mathrm{Pb}$ from wastewaters is controlled by DO, DOC and Eh. Redox potential is of major concern for mobilization of trace metals in estuaries where an oxygen gradient exists in addition to the salinity gradient (Gerringa et al., 2001). Besides, this studies showed that similar to the findings of Biati et al (2010b) mechanisms for flocculation of Pb is still unknown and further investigations is needed to find out governing factors in the flocculation of $\mathrm{Pb}$. Moreover, Karbassi et al (2008b) stated that $\mathrm{pH}$ and $\mathrm{PO}_{4}$ control flocculation of $\mathrm{Cu}$ in Babolrud estuarine process.

Since salinity is a general term that does not necessarily show the effect of other constituents of the saline water on elemental flocculation in estuaries, other constituents of Sea water might be involved in the flocculation processes. Many studies show that salinity and $\mathrm{pH}$ are the main factors in the flocculation of metals during estuarine mixing (Boyle et al., 1977; Duinker et al, 1983; Hunter, 1983; Zhiqing et al., 1987). Contrary to the findings of Biati et al (2010b) that DOC showed a non-liner and conservative behavior during mixing of Minab river water with the Persian Gulf water; conservative DOC behavior is reported for estuarine mixing in Beaulieu estuary(Moore, et al., 1979). Karbassi et al. (2008b) reported linear DOC increase for the rivers flowing in to the Caspian Sea. In contrast, a linear DOC decrease over salinity range of 17 to $28 \%$ is reported for Bristol channel (Mantaura and Mann, 1979). Although studies of rivers flowing in to the Caspian Sea indicate that DOC increase with an increases in salinity that could be indicative of non- terrigenous DOC (Karbassi et al., 2007; Karbassi et al., 2008 a,b), study of flocculation process in Minab River in South of Iran showed that DOC originates from terrigenous source and Persian Gulf waters do not contribute to DOC contents of Minab estuary (Biati et al, 2010b). Removal of significant amounts of riverine DOC may occur due to flocculation or precipitation reactions that result in the conversion of DOC to particulate organic carbon and their subsequent settlement on to the sediments (Sholkovitz, 1976). Production of autochthonous DOC in estuaries may also occurs through several processes (Sharp, 1991). Aquatic fulvic acids accounts for 50 to $80 \%$ of the total amount of DOC in coastal waters (Krachler, et al., 2005). The reasons for such increase in DOC concentrations from rivers to the Caspian Sea in North of Iran, which may be related to exudation by microalgae require further studies.

Table 3 summarizes the governing factors that control flocculation of trace metals during estuarine mixing for Minab, Tadjan, Talar, Babolrud, Haraz and Shirud Rivers. As can be seen in Table 3, $\mathrm{PO}_{4}$ is one of the factors that affects flocculation of elements (e.g. $\mathrm{Cu}$ ) in Babolrud estuarine mixing. It should be pointed out that the processes responsible for removal of dissolved $\mathrm{PO}_{4}$ at high concentrations encountered in the Babolrud estuary include precipitation of apatite (calcium phosphate), viviane (ferrous phosphate) and magnesium- ammonium phosphate but these have not been indentified in situ or in laboratory experiments simulating estuarine conditions (Deck, 1981; Saeedi et al., 2003). Considering the mean discharge of the rivers (Table 3) concentrations of dissolved metals in river water and also percentage of elemental removal via estuarine mixing (Table 2), amount of elemental load entering to the Sea and removal of dissolved metals due 
Int. J. Environ. Sci. Tech., 7 (4), 731-736, Autumn 2010

Table 3: Controlling parameters of flocculation along with amount of elemental removal via flocculation in six rivers

\begin{tabular}{|c|c|c|c|c|c|c|c|c|c|c|}
\hline River & $\mathrm{pH}$ & Eh & $\begin{array}{c}\text { S } \\
(\% o)\end{array}$ & DOC & $\mathrm{PO}_{4}$ & $\begin{array}{l}\text { cculation } \\
\text { Total } \\
\text { nitrogen } \\
\left(\mathrm{N}_{\mathrm{T}}\right)\end{array}$ & EC & $\begin{array}{l}\text { Removal via } \\
\text { flocculation } \\
(\text { Ton/y) }\end{array}$ & $\begin{array}{l}\text { Dissolved } \\
\text { elemental } \\
\text { load entering to } \\
\text { the sea (Ton/y) }\end{array}$ & $\begin{array}{l}\text { Mean discharge } \\
\text { of river } \\
\left(\mathrm{m}^{3} / \mathrm{y}\right)\end{array}$ \\
\hline Minab & 0 & - & O & + & $x$ & $\times$ & 0 & 135.2 & 55.7 & $347 \times 10^{6}$ \\
\hline Tadjan & + & $x$ & - & $x$ & $x$ & $x$ & - & 37.4 & 10.727 & $246 \times 10^{6}$ \\
\hline Talar & + & $x$ & o & ० & $x$ & + & o & 54.1 & 49.63 & $440 \times 10^{6}$ \\
\hline Babolrud & + & $x$ & o & 0 & + & ० & 0 & 27.3 & 45.9 & $560 \times 10^{6}$ \\
\hline Haraz & + & $x$ & o & ० & ○ & + & o & 122.6 & 97.02 & $940 \times 10^{6}$ \\
\hline Shirud & $x$ & $x$ & + & $x$ & $x$ & $x$ & $x$ & 15.9 & 10.6 & $127 \times 10^{6}$ \\
\hline
\end{tabular}

+: Governs; -: Inhibits; ○: No effect; $\times$ : No information

to flocculation process are estimated. The highest elemental removal during estuarine mixing can be found in Minab River where approximately 135 ton/y of dissolved metals are flocculated and the lowest removal via flocculation processes occurs in Babolrud River (27.3 ton/y). Therefore, it can be concluded that higher initial concentration of elements in river water and mean discharge of river may lead to higher flocculation rates. Removal of dissolved elements in the 6 mentioned river is in the following order:

Minab (135.2 ton/y) > Haraz (122.6 ton/y) > Talar (54.1 ton/y) > Tadjan (41.5 ton/y) > Babolrud (27.3 ton/y) > Shirud (10.91 ton/y).

The highest and the lowest dissolved elemental load flow to the Caspian Sea via Haraz river (97.02 ton/y) and Shirud (10.6 ton/y), respectively. General pattern for dissolved loads of elements flowing into the Caspian Sea and Persian Gulf is as follow: Haraz (97.02 ton/y) > Minab (55.7 ton/y) > Talar (49.63 ton/y) > Babolrud (45.9 ton/y) $>$ Tadjan (10.73 ton/y) $>$ Shirud (8.57 ton/y).

\section{CONCLUSION}

Flocculation process of dissolved $\mathrm{Zn}, \mathrm{Cu}, \mathrm{Mn}, \mathrm{Ni}$ and $\mathrm{Pb}$ during estuarine mixing of Minab River flowing in to the Persian Gulf and five rivers flowing in to the Caspian Sea have been compared with one another. The results showed that maximum removal of elements occurs in lower salinities (1.5 to $5.8 \%$ ) for the rivers in North of Iran and 3.3 to $11.4 \%$ for Minab River in South of Iran. The main governing factor that plays significant role in flocculation of dissolved metals in Minab River estuarine zone is DOC (except for $\mathrm{Pb}$ ) but in the other rivers flocculation is mainly controlled by $\mathrm{pH}$ and total nitrogen $\left(\mathrm{N}_{\mathrm{T}}\right)$ and also $\mathrm{PO}_{4}$ in Babolrud and salinity in Shirud estuaries. Other physical- chemical parameters of water does not play important role in flocculation process. Contrary to the northern coastal waters of Iran source of DOC in Minab River (in southern part of Iran) is terrigenous. Further investigation is suggested on more and detailed role of other constituents of seawater in flocculation of trace metals during estuarine mixing.Flocculation of studied metal in different rivers shows that the overall metal pollution load can be reduced by various percentages. The initial metal contents on river water and mean discharge of river might lead to higher flocculation rates.

\section{ACKNOWLEDGMENTS}

The authors would like to thank Laboratory Complex of Science and Research Branch, National Center for Oceanography and Persian Gulf and Oman Sea Ecological Research Institute for extending laboratory facilities.

\section{REFERENCES}

Achterberg, E. P.; Herzl, V. M. C.; Braungardt, C.B.; Millward, G. E.; (2003). Metal behaviour in an estuary polluted by acid mine drainage: The role of particulate matter. Environ. Pollut., 121 (2), 283-292 (10 pages).

Anderson, A. J. B. (1971). Numerical examination of multivariate soil samples. Math. Geol. 3 (1), 1-14 (14 pages).

Anikiev, V. V.; Goryachev, N. A. (1991). Heavy metals behavior at mixing between marine and riverine waters. Geokhimiya, 11, 6-42 (37 pages).

Bewers, J. M.; Mac, A. I. D.; Sundby, B., (1974). Trace metals in the waters of Gulf of St. Lawrence. Can. J. Earth Sci., 11, 939-950 (12 pages).

Biati. A.; Moattar, F.; Karbassi, A. R.; Hassani, A. H., (2010a). Role of saline water in removal of heavy elements from industrial wastewaters. Int. J. Environ. Res., 4 (1), 169176 (8 pages).

Biati. A.; Karbassi, A. R.; Hassani, A. H.; Monavari, S. M.; Moattar, F., (2010b). Role of metal species in flocculation rate during estuarine mixing. Int. J. Environ. Sci. Tech., 7 (2), 327-336 (10 pages).

Boyle, E.A.; Edmond, J. M.; Sholkovitz, E. R., (1977). The mechanism of $\mathrm{Fe}$ removal in estuaries. Geochim. Cosmochim. Acta., 41 (9), 1313-1324 (12 pages).

Davis, J. B., (1973). Statistic and data analysis in geology. Wiley, New York, 456-473 (18 pages). 
Deck, B. L., (1981). Nutrient-element distribution in Hudson estuary. Ph.D. thesis. Columbia University, New York.

Duinker, J.C.; Nolthing, R. F., (1978). Mixing, removal and mobilization of trace metals in the Rhine estuary. Neth. J. Sea Res., 12, 205-223 (19 pages).

Duinker, J. C.; Nolting, R. F.; Michel, D., (1983). Effects of salinity, $\mathrm{pH}$ and redox conditions on the behavior of $\mathrm{Cd}, \mathrm{Zn}$, $\mathrm{Ni}$ and $\mathrm{Mn}$ in the Scheldt estuary. Thalassia Jugosl., 18, 191201 (11 pages).

Eckert, J. M.; Sholkovitz, E. R., (1976). The flocculation of Fe, $\mathrm{Al}$ and humates from river water by electrolytes. Geochim. Cosmochim. Acta., 40 (7), 847-848 (2 pages).

Featherstone, A. M., O’Grady, B. V., (1997). Removal of dissolved $\mathrm{Cu}$ and $\mathrm{Fe}$ at the freshwater - seawater interface of an acid mine stream. Mar. Poll., 34 (5), 332-337 (6 pages).

Gerringa, L. J. A.; de Baar, H. J. W.; Nolthing, R. F.; Paucot, H., (2001). The influence of salinity on the solubility of $\mathrm{Zn}$ and Cd sulfides in the Scheldt estuary. Sea Res., 46, (3-4) 201-211 (11 pages)

Hassani, A. H.; Seif, S.; Javid, A. H.; Borghei, M., (2008) Comparison of Adsorption Process by GAC with Novel Formulation of Coagulation - Flocculation for Color Removal of Textile Wastewater. Int. J. Environ. Res., 2 (3), 239-248 (10 pages).

Hunter, K. A., (1983). On the estuarine mixing of dissolved substances in relation to colloidal stability and surface properties. Geochim. Cosmochim. Acta., 47 (3), 467-473 (7 pages).

Karbassi, A. R.; Nadjafpour, S., (1996). Flocculation of dissolved $\mathrm{Pb}, \mathrm{Cu}, \mathrm{Zn}$, and $\mathrm{Mn}$ during estuarine mixing of river water with the Caspian Sea. Environ. Pollut., 93, 257-260 (4 pages).

Karbassi, A. R.; Nouri, J.; Ayaz, G. O., (2007). Flocculation of trace metals during mixing of Talar river water with Caspian seawater. Int. J. Environ. Res. 1 (1), 66-73 (8 pages).

Karbassi, A. R.; Nouri, J.; Mehrdadi, N.; Ayaz, G. O., (2008a). Flocculation of heavy metals during mixing of freshwater with Caspian seawater. Environ. Geol., 53 (8), 1811-1816 (6 pages).

Karbassi, A. R.; Nouri, J.; Nabi Bidhendi, Gh. R.; Ayaz, G. O., (2008b). Behavior of $\mathrm{Cu}, \mathrm{Zn}, \mathrm{Pb}, \mathrm{Ni}$ and Mn during mixing of freshwater with the Caspian seawater. Desalination, 229 (13), 118-124 (7 pages).

Krachler, R.; Jirsa, F.; Ayromlou, S., (2005). Factors influencing the dissolved iron input by river water to the open ocean. Biogeosciences Discussions., 2, 537-549 (13 pages).

Lance, G. N.; William, W. T., (1966). A Generalized sorting for computer classification. Nature. 212-218 (7 pages).

Mantoura, R. F. C.; Mann, S. V., (1979). Dissolved organic carbon in estuaries. In: Severn, R. T.; Dineley, D., Hawker, L. E. (Ed.) Tidal power and estuary management. Bristol,
Scientechnical. 279-286 (8 pages).

Martoura. R. F. C.; Woodward, E. M. S., (1983). Conservative behavior of riverine dissolved organic carbon in the Severn estuary: Chemical and geochemical implications. Geochim. Cosmochim. Acta., 47 (7), 1293-1309 (17 pages).

Matagi, S. V.; Swai, D.; Mugabe, R., (1998). A review of heavy metal removal mechanisms in wetlands. Afr. J. Trop. Hydrobiol. Fish., 8 (1-2), 23-25 (3 pages).

Meire, P.; Ysebaert, T.; Van Damme, S.; Van den Bergh, E.; Maris, T.; Struyf, E., (2005). The Scheldt estuary: A description of a changing ecosystem. Hydrobiologia, 540 (13), 1-11 (11 pages).

Meyer, J. L., Tate, C. M., (1983). The effects of watershed disturbance on dissolved organic carbon dynamics of a stream. Ecology., 64 (1), 33-44 (12 pages).

Moor. R. M.; Burton, J. D.; Williams, P. J. B.; Young, M. L., (1979). The behavior of dissolved organic material, Fe and $\mathrm{Mn}$ in estuarine mixing. Geochim. Cosmochim. Acta., 43 (6), 919-926 (8 pages).

Pritchard, D. W. (1967). What is an estuary: Physical viewpoints. Estuaries, G. H. Lauff (Ed.). Publication No. 83, American Association for the Advanced of Science, Washington, D. C., 3-5 (3 pages).

Saeedi, M.; Karbassi, A. R., Mehrdadi, N. (2003). Flocculation of dissolved $\mathrm{Mn}, \mathrm{Zn}, \mathrm{Ni}$ and $\mathrm{Cu}$ during the estuarine mixing of Tadjan river water with Caspian seawater. Int. J. Environ. Stud., 60 (6), 567-576 (10 pages).

Samarghandi, M. R.; Nouri, J.; Mesdaghinia, A. R.; Mahvi, A. H.; Nasseri, S.; Vaezi, F., (2007). Efficiency removal of phenol, lead and cadmium by means of UV/TiO2/H2O2 processes. Int. J. Environ. Sci. Tech., 4 (1), 19-25 (7 pages).

Savchenko, A. V., Gramm-Osipov, L. M., Mar'yash, A. A (2009). Physicochemical modeling of the behavior of microelements (As, V, Cr, Co and Hg) under the mixing of riverine and marine waters (the Razdol'naya River-Amur Bay system). Oceanology, 49 (1), 39-46 (8 pages).

Shankar, R.; Karbassi, A. R., (1992). Flocculation of Cu, Zn, Ni and Fe during mixing of Mulki river water and Arabian seawater, west of India. Proceedings of $7^{\text {th }}$ international symposium on water rock interaction, Utah, USA, 565-568 (4 pages).

Sharp, J. H., (1991). Review of carbon, nitrogen and phosphorus biogeochemistry. Rev. Geophys., 29, 648-657 (10 pages).

Shokovitz, E. R., (1976). Flocculation of dissolved organic and inorganic matter during the mixing river water and seawater. Geochim. Cosmochim. Acta., 40 (7), 831-845 (15 pages).

Sholkovitz, E. R.; Boyle, E. A.; Price, N. B., (1977). Removal of dissolved material in the Amazon estuary. Eos. Trans. Am. Geophys. Union., 5, 423-439 (17 pages).

Zhiqing. L. E., Jianhu, Z., Jinsi, C., (1987). Flocculation of dissolved $\mathrm{Fe}, \mathrm{Al}, \mathrm{Mn}, \mathrm{Si}, \mathrm{Cu}, \mathrm{Pb}$ and $\mathrm{Zn}$ during estuarine mixing. Acta Oceanol. Sin., 6 (44), 567-576 (10 pages).

\section{AUTHOR (S) BIOSKETCHES}

Biati, A., Ph.D. Scholar, Department of Environmental Science, Graduate School of the Environment and Energy, Science and Research Branch, Islamic Azad Universty, Tehran, Iran. Email: bayati_id@yahoo.com

Karbassi, A. R., Ph.D., Assistant Professor, Department of Environmental Engineering, University of Tehran, Tehran, Iran. Email: akarbassi@ut.ac.ir

How to cite this article: (Harvard style)

Biati, A.; Karbassi, A. R., (2010). Comparison of controlling mechanisms of flocculation processes in estuaries. Int. J. Environ. Sci. Tech., 7 (4), $731-736$ 